\title{
Contextualising the Influence of Socialization Agents in Shaping Primary School Pupils Behaviour in Thika Sub-County, Kenya
}

\author{
Esther Wanjiru Mwangi 1*, Catherine Ndung’u 2, Michael Gachahi ${ }^{2}$ \\ ${ }^{1}$ Karatina University, 1957-10101 Karatina, KENYA \\ ${ }^{2}$ School of Education and Social Sciences, Karatina University, KENYA \\ *Corresponding Author: esthermwangiw@gmail.com \\ Citation: Mwangi, E. W., Ndung'u, C. and Gachahi, M. (2018). Contextualising the Influence of \\ Socialization Agents in Shaping Primary School Pupils Behaviour in Thika Sub-County, Kenya. Pedagogical \\ Research, 3(3), 11. https://doi.org/10.20897/pr/3929
}

Published: October 16, 2018

\begin{abstract}
Socialization agents shape pupils' behaviour. Pupils' behaviour has deteriorated over time in primary schools in Kenya. The purpose of the study was to contextualise the influence of socialization agents in shaping primary school pupils in Thika Sub County. The objective of the study was to assess the role of school variables in shaping pupils' behaviour. Descriptive research design was applied with a target population comprising of 570 teachers, 3256 pupils and 69 head teachers. The sample size consisted of 57 teachers, 325 class seven pupils and 7 school heads. The research instruments used consisted of the teachers and pupils questionnaire and an interview guide for head teachers and sub county director of education. The research instruments were piloted and a correlation coefficient of $<0.7$ was acceptable. Data was analyzed using both descriptive and inferential statistics with the aid of the Scientific Package for Social Sciences (SPSS). The study established that the school rules played a key role in management of children's behaviour in school since they maintained socially acceptable norms within the school. However the school rules did not dictated the form of punishment for non-compliance. The school should carry out background checks on learners in order to establish behavioural issues that are likely to face from a particular set of learners. This would assist in discipline management in schools. The teachers should also consider prior behavioural and discipline issues in order to determine how to address the current pupils' indiscipline. The school administrators should ensure that the school rules specify the punishment for various issues of nonadherence to the rules. This would assist in having uniform forms of punishment and thus learners would understand the punishments and the role of punishment in shaping their behaviour.
\end{abstract}

Keywords: socialization, school as an agent, pupils behaviour

\section{INTRODUCTION}

Scaglioni et al. (2008) noted that during the early years, parents are key in developing the child's growth and development. This affects the children perception and behaviour patterns. To mold good society acceptable behaviour, the children are discouraged from adopting negative behaviour and at the same time reinforced to adopt positive behaviour. Saleem and Anderson (2012) noted that the normally the behaviour of a child during formative years was entrusted to the whole society. Any adult could have disciplined a child who was found behaving against the social norms of where the child was born. Today the child's behaviour is either left to the teacher or the parent. Giddens (2006) adds that the fact that the teacher spends most of the time with the child and therefore the teacher is expected to mould the child in all aspects. However, the strategy the teacher uses to instill positive behaviour is controlled. For example, a teacher is not supposed to cane a child as a method of behaviour modification. It is 
against the Kenyan law and child rights. Any teacher found doing so is likely to face the law or even disciplinary action.

\section{RESEARCH OBJECTIVE}

The objective of this study was to assess the role of school in shaping children's behaviour in primary schools in Thika Region.

\section{EMPRICAL REVIEW}

Bartkowski et al. (2008) also agree that the school provides opportunities for skill development throughout the program, such as resilience, social, coping and communication skills and protective behaviours. They added that schools explicitly teach appropriate behaviours and play skills, building on children's strengths and prior knowledge and also provide opportunities for children to practice appropriate behaviours. DECS (2004) agrees that schools use assessment, monitoring and reporting procedures that focus on children's progress and achievements and also work together as a team, using a consistent approach.

DECS (2004) argues that schools should note deviant behaviour and correct it immediately. DECS (2004) notes that a timely and appropriate response is evident where early identification of challenging behaviours occurs. They also concur that communication with families about challenging behaviours takes place at the earliest opportunity and is framed as a positive opportunity to address children's behavioural needs within the group setting. Anckle (2011) agrees that schools will use the Behaviour Support Policy for Early Childhood Services (BSPEC) to further develop site behaviour codes. Site behaviour codes describe a positive and proactive approach to supporting children's development of appropriate behaviours and the site's behavioural expectations and consequences. They note that many education supervisors all over the world have behaviour codes which are developed in partnership with government agencies and school management committees, families and relevant members of the local community.

Blaya and Debarbieux (2008) noted that traditionally, in Western schools, indiscipline was met with corporal punishment. A head teacher of Eton, a prestigious public school of Britain is said to have whipped more than eighty boys in a single day. In most European countries, corporal punishment in school has been abolished. Most African countries that follow British educational traditions allow the school to administer physical punishment under certain conditions. A growing tendency everywhere is to authorize only the head teacher to mete out punishment. In Kenya, The Children's Act has prohibited corporal punishment. Therefore the teachers are prohibited from meting corporal punishment and have resulted in other forms of discipline management such as manual work within the school as well as guidance and counseling. There is some evidence that corporal punishment is still used in African schools and often preferred to other punitive measure and positive incentives (Watson, 2003).

Bosworth (2000) indicated that the school class assesses the pupil's achievement cognitively and morally. Cognitive area covers acquisition of information, skills, frames of references related to facts, the written language and mathematical thinking. Muller (2001) indicated that moral aspect is generally co-terminus with citizenship training. Muller further posited that this begins with respect for the teacher, friendliness towards classmates and good work habits such as punctuality and gratification, but aims at culminating in the capacity for leadership and initiative. The teacher becomes a mediator of knowledge, a parent substitute, a confidant, a disciplinarian and a representative of the moral values of the dominant group in the society. However, this comes with challenges whereby disturbances in classroom activities obstruct the process of pupil's socialization and this may require imposition of external standards and controls on pupil's behaviour. Battistich et al. (2000) noted that when students find their school environment to be supportive and caring, they are less likely to become involved in substance abuse, violence, and other problem behaviours. Osterman (2000) notes that the children are more likely to develop positive attitudes toward themselves and pro-social attitudes and behaviours toward others. Watson (2003) shows that supportive schools foster these positive outcomes by promoting students' sense of connectedness, belongingness or community during the school day. Osterman (2000) noted that among children, positive reinforcement assists in shaping students behaviour and that this reinforcement could be in form of tangible rewards in the form of prizes and social rewards such as teacher attention, encouragement and praise (Osterman, 2000). Punishment includes sarcasm, ridicule, and denial of participation in such facilities as sport and weekend outings.

Osterman (2000) also noted that school rules can shape and influence the way that a child behaves. He argues that the rules are the basic set of expectations for behaviour that the child must follow during the academic day. Failure to follow school rules results in negative consequences such as detention or even, in extreme cases, 
Pedagogical Research, 3(3), 11

Table 1. The Role of School in Shaping Children's Behaviour

\begin{tabular}{|c|c|c|c|c|c|}
\hline Statement & $\begin{array}{c}\text { Strongly } \\
\text { agree }\end{array}$ & Agree & $\begin{array}{c}\text { Non- } \\
\text { committal }\end{array}$ & Disagree & $\begin{array}{l}\text { Strongly } \\
\text { disagree }\end{array}$ \\
\hline The school carries out background analysis on the pupil's background on admission & $0.00 \%$ & $14.80 \%$ & $0.00 \%$ & $35.20 \%$ & $50.00 \%$ \\
\hline $\begin{array}{l}\text { As a teacher I enquire on my pupils' family background when dealing with behaviour } \\
\text { issues }\end{array}$ & $0.00 \%$ & $38.90 \%$ & $0.00 \%$ & $48.10 \%$ & $13.00 \%$ \\
\hline $\begin{array}{l}\text { The school recognizes pupils who have rectified their behaviour outside academic } \\
\text { prowess }\end{array}$ & $0.00 \%$ & $13.00 \%$ & $37.00 \%$ & $33.30 \%$ & $16.70 \%$ \\
\hline $\begin{array}{l}\text { The school rules assist in maintenance of socially acceptable behaviour among } \\
\text { learners }\end{array}$ & $50.00 \%$ & $35.20 \%$ & $1.90 \%$ & $13.00 \%$ & $0.00 \%$ \\
\hline The rules act as a tool to maintain socially acceptable norms within the school & $48.10 \%$ & $46.30 \%$ & $0.00 \%$ & $5.60 \%$ & $0.00 \%$ \\
\hline The school rules do not discriminate on learners & $25.90 \%$ & $74.10 \%$ & $0.00 \%$ & $0.00 \%$ & $0.00 \%$ \\
\hline The rules dictate penalties if breached & $14.80 \%$ & $31.50 \%$ & $0.00 \%$ & $16.70 \%$ & $37.00 \%$ \\
\hline The penalties breached are issued with strict obedience & $9.30 \%$ & $9.30 \%$ & $5.60 \%$ & $37.00 \%$ & $38.90 \%$ \\
\hline In disciplining a child, prior cases of indiscipline are considered & $46.30 \%$ & $31.50 \%$ & $3.70 \%$ & $14.80 \%$ & $3.70 \%$ \\
\hline
\end{tabular}

expulsion. Watson (2003) noted that a school might provide general student rules that include being respectful of teachers and other students and being responsible for their own actions along with consequences for misbehaviour. For example, an elementary school might state that all students must act in a respectful manner toward teachers, listen attentively, not talk back and obey all directions that the teacher gives. If a student breaks the rule, her behaviour might result in meeting with the principal, a call to the parents, verbal warnings, written warnings or recess detention.

In Kenya, the education cycle is 3years in pre-school, 8years in primary and 4 years in secondary. Class activities are planned for deliberate purpose of teaching literacy, numeracy and development of self-expression, discipline, reliance and appreciation of labour and one's cultural heritage. Extracurricular activities such as sports, clubs and drama are intended to train the learners for life in the larger society.

The literature above shows that a child spends more time in school. It has also demonstrated that the school shapes children behaviour through personal interactions with teachers and administrators. The literature has also shown the potential of school rules and regulations in shaping a child's behaviour.

\section{FINDINGS}

Data showed that a significantly low proportion (14.8\%) of the participants agreed that their schools carry put background analysis on learners prior to admission. The study established that majority of teachers did not check the pupils background to assist them discern the cause of indiscipline and thereby reach a better way of assisting children to reform their behaviour. This blanket condemnation denied teachers an opportunity to find a long lasting solution to children's behavioural issues. The findings discussed above are divergent with Bartkowski et al. (2008) who argued that in addressing learners' discipline issues, teachers should focus on understanding the genesis of the behaviour through background checking in order to address the cause of indiscipline. By identifying causal factors teachers are able to devise appropriate rewards or punishment to assist learners readjust and be socially in line with the societal values.

Majority $(85.2 \%)$ of the teachers agreed that the school rules act as a tool to maintain socially acceptable norms within the school. Majority (53.7) of the teachers noted that the school rules did not specify punishment for noncompliance with rules. Thus individual teachers determined the type of punishment to vet on learners who broke the rules. The punishment for on-adherence was not uniform as it varied depending on the teachers involved. Lack of prescribed form of punishment or discipline mechanism opens the primary school punishment to abuse by teachers and might not address the pupils' discipline management. The study found out that the teachers agreed that school rules assist in behaviour management among pupils in primary schools. These findings concur with Osterman (2000) that the core purpose of school rules in educational institutions is to influence the learners' conduct and behaviour in a certain predetermined way. By influencing learners' behaviour, school rules assist in discipline management of learners since they introduce rewards and punishment for adherence and non-adherence.

The study also established that majority $(77.8 \%)$ of the teachers agreed that they considered learners past discipline cases when dealing with current indiscipline The study established that schools consider previous cases of pupil indiscipline to determine the punishment to render to current cases. The study established that schools consider previous cases of pupil indiscipline to determine the punishment to render to current cases. The study agrees with Bosworth (2000) that the school should assess the learners' prior records in order to determine the rewards or punishment to render to particular issues. This is because once a trend is observed mitigating environments can be created to avoid pupil negative behaviour. 


\section{CONCLUSIONS}

The study thus established that majority of the schools do not carry out prior checking of learner's history before admission. This means that learners are admitted without checking on their discipline in previous schools although cases of learners transfers were not many at primary education level. The study established that majority of teachers did not check the pupils background to assist them discern the cause of indiscipline and thereby reach a better way of assisting children to reform their behaviour. This blanket condemnation denied teachers an opportunity to find a long lasting solution to children's behavioural issues.

The study finds that the teachers agreed that school rules assist in behaviour management among pupils in primary schools. This study holds that school rules should spell out the punishment for non-compliance in order to avoid punishment being dependent on the teachers' personality. This would assist to shape learners behaviour since the form and type of punishment will be known before issues of non-compliance to school rules arise.

\section{RECOMMENDATIONS}

The school administration should carry out learners discipline cases from previous schools before admission to current school. This would ensure that the learners discipline and behaviour is easily identified on joining the current school and strategies to assist the learners change their behaviour through guidance and counseling starts off immediately upon admission.

The school administrators should ensure that the school rules specify the punishment for various issues of nonadherence to the rules. This would assist in having uniform forms of punishment and thus learners would understand the punishments and the role of punishment in shaping their behaviour.

The schools should also have a learner discipline book where various issues of indiscipline by individual learners are tracked. This would assist the guidance and counseling teachers when such learners are referred to them for behaviour management.

\section{REFERENCES}

Anckle, D. (2011). Behaviour Management in Children. Unpublished Workshop Material.

Bartkowski, J. P., Xu, X. and Levin, M. (2008). Religion and Child Development: Evidence from the Early Childhood Longitudinal Study. Social Science Research, 37, 18-36. https://doi.org/10.1016/j.ssresearch.2007.02.001

Battistich, V., Schaps, E., Watson, M., Solomon, D. and Lewis, C. (2000). Effects of the child development thesis on students' drug use and other problem behaviours. Journal of Primary Prevention, 21(1), 75-99. https://doi.org/10.1023/A:1007057414994

Blaya, C. and Debarbieux, E. (2008). Gangs and ethnicity: An interactive construction. The role of school segregation. In F. Van Gemet, D Peterson and I-L, Liese. Youth gangs, migration and ethnicity. London: William Publishers.

Bosworth, K. (2000). Protective Schools: Linking Drug Abuse Prevention with Student Success. Tucson: The University of Arizona.

DECS. (2004). Supporting and Managing Children's Behaviour: An Early Childhood Resource. South Australia: Gillingham Printers.

Giddens, A. (2006). Sociology, 5th Ed. USA Polity Press.

Muller, C. (2001). The role of caring in the teacher-student relationship for at-risk students. Sociological Inquiry, 71(2), 241-255. https://doi.org/10.1111/j.1475-682X.2001.tb01110.x

Osterman, K. (2000). Students' Need for Belonging in School. Review of Educational Research, 70(3), 323-367. https://doi.org/10.3102/00346543070003323

Saleem, M. and Anderson, C. A. (2012). The Good, the Bad and the Ugly of Electric Media. New York. Oxford University Press

Scaglioni, S., Salvioni, M. and Galimberti, C. (2008).Influence of Parental Attitudes in the Development of Children Eating Behaviour. British Joumal of Nutrition Supplementary Issue, 1, 15-18.

Watson, M. (2003). Learning to Trust. San Francisco: Jossey-Bass. 